\title{
Isolation, Cellulase Activity Test and Molecular Identification of Selected Cellulolytic Bacteria Indigenous Rice Bran
}

\author{
Akyunul Jannah ${ }^{1,2, *}$, Aulanni ${ }^{2}{ }^{3}{ }^{3}$ Tri Ardyati $^{1}$, and Suharjono ${ }^{1}$ \\ ${ }^{1}$ Department of Biology, Brawijaya University, Jl. Veteran 6, Malang 65144, East Java, Indonesia \\ ${ }^{2}$ Department of Chemistry, Maulana Malik Ibrahim State Islamic University Malang, \\ Jl. Gajayana 50 Dinoyo, Malang 65144, East Java, Indonesia \\ ${ }^{3}$ Faculty of Veterinary Medicine, Brawijaya University, Jl. Puncak Dieng Dau, Malang 65151, East Java, Indonesia
}

Received July 19, 2017; Accepted May 24, 2018

\begin{abstract}
Rice bran is the waste product of rice milling which is abundant in Indonesia, it can be used as a raw material for the manufacture of bioethanol by fermentation. Before being fermented, rice bran must be hydrolyzed into glucose by biomass degrading. This study was aimed to isolate indigenous cellulolytic bacteria from rice bran as producer of cellulolytic enzymes and resulted in 22 bacterial isolates that demonstrated cellulolytic activity being identified. Among them, BE 8 and BE 14 isolates showed the highest endoglucanase activity at 2.16 and $1.31 \mathrm{U} / \mathrm{mL}$ respectively. Identification of the $16 S$ rDNA showed that BE 8 belongs to Bacillus subtilis and BE 14 in Bacillus cereus.
\end{abstract}

Keywords: cellulase enzyme; rice bran; 16S rDNA method; Bacillus subtillis; Bacillus cereus

\section{ABSTRAK}

Bekatul (Rice bran) merupakan limbah dari hasil penggilingan padi yang jumlahnya cukup melimpah di Indonesia sehingga bisa dimanfaatkan sebagai bahan baku untuk pembuatan bioetanol dengan cara fermentasi. Sebelum fermentasi maka bekatul harus dihidrolisis menjadi glukosa menggunakan enzim selulase. Tujuan dari studi ini untuk mengisolasi bakteri selulolitik indigenous bekatul sebagai penghasil enzim selulase sehingga diperoleh isolat yang stabil dan sesuai dengan substrat bekatul. Hasil isolasi dan skrining menunjukkan ada 25 isolat bakteri indigenous bekatul dan 22 isolat bakteri yang menunjukkan adanya aktivitas selulolitik. Pada uji aktivitas selulase dari 6 isolat terpilih menunjukkan bahwa isolat BE 8 dan BE 14 menunjukkan aktivitas endoglukanase tertinggi dengan nilai masing-masing 2,16 dan 1,31 U/mL. Berdasarkan identifikasi $16 S$ rDNA menunjukkan bahwa isolat BE 8 adalah Bacillus subtilis dan isolate BE 14 adalah Bacillus cereus.

Kata Kunci: enzim selulase; bekatul; metode 16S rDNA; Bacillus subtillis; Bacillus cereus

\section{INTRODUCTION}

Bioethanol receives much attention as an alternative to petroleum-based energy sources. The advantages of bioethanol as compared to petroleum are that it has a higher octane number, higher flame speed, more combustible, and gives higher vaporization heat that provides a higher compression ratio and a shorter burn time in the internal combustion engine [1]. Over the period 1990 to $2020, \mathrm{CO}_{2}$ emissions from road traffic around the world will have increased by $92 \%$ [2]. The more complete combustion of Bioethanol fuel is due to it contains $35 \%$ of the oxygen that it will reduce particulate and NOx emissions [3].

Bioethanol production in Indonesia focuses on the use of starchy materials such as cassava and corn, and it is feared that this may potentially lead to the decrease

* Corresponding author.

Email address : akyunul_jannah2008@yahoo.com of biodiversity through monoculture, and agricultural practices that damage the quality of lands [4], and create continuing problems of raw material supply and price fluctuations. These issues can be solved by diversifying the starchy raw materials used for bioethanol production by utilizing the waste products of rice milling, such as rice bran.

Indonesia is one of the largest rice producers and consumers in Asia. The rice production in 2017 is expected to have increased by $3.9 \%$ from the 72 million metric tons produced in 2016 [5]. The rice bran obtained from rice milling amounts to approximately $17 \%$ [6] or about 13 million tons available annually. Rice bran contains $25 \%$ carbohydrates, composed of $22-25 \%$ insoluble fibers (such as cellulose) and $0.1-$ $1.5 \%$ soluble fiber, $16-19.5 \%$ protein, $17-20 \%$ fat, and $7-8 \%$ minerals [7]. The high level of carbohydrates, in

Akyunul Jannah et al. 
particular cellulose, in rice bran can serve as a potential source of raw materials in the manufacture of bioethanol [8].

Cellulose is a polymer of glucose linked by $\beta-1,4$ glucosidase bond with a crystalline structure that is stabilized by intermolecular and intramolecular hydrogen bonds [9]. Cellulase enzymes can degrade the crystalline structure into glucose that can be used as raw material for bioethanol. Cellulase enzymes can be produced by microorganisms such as fungi and bacteria. Cellulase-producing bacteria have a high growth rate, meaning for them to degrade cellulose is shorter than for fungi [10]. Bacteria also secrete smaller cellulases than fungi which therefore diffuse more quickly into plant tissues that contain cellulose [11], their rate of growth is faster, they adapt successfully to extreme environments and it is easier to perform genetic engineering on them [12].

The cellulase enzyme is a multienzyme system comprising the complexes endo- $\beta$-1,4-glucanase (CMCase; EG; EC 3.2.1.4), exo- $\beta$-1,4-glucanase (cellobiohydrolase; $\mathrm{CBH}$; $\mathrm{EC}$ 3.2.1.91), and $\beta-1,4$ glucosidase $(\mathrm{GH} ; \mathrm{EC}$ 3.2.1.21). The enzyme system works in synergy to degrade cellulose substrate. Some cellulose-producing fungi generate incomplete cellulase systems which affects the cellulose's performance in cellulose degradation. Trichoderma reesei produces endo- $\beta$-1,4-glucanase and exo- $\beta$-1,4-glucanase up to $80 \%$ but $\beta$-glucosidase is lower than the main product of the hydrolysis instead of glucose and cellobiose [13]. Aspergillus niger is one of the commonly used for hydrolyzing cellulose. This microorganism produces high amounts of $\beta$-glucosidase but low amounts of endo- $\beta$ 1,4 -glucanase and exo- $\beta-1,4$ glucanase [14]. The Bacillus circulans has levels of high activity in terms of CMCase (endo- $\beta-1,4$-glucanase), avicelase (exo- $\beta-1,4-$ glucanase) and $\beta$-glucosidase [15]. Therefore, this study aimed to isolation, identify cellulolytic bacteria from rice bran as cellulase producers, with the expectation that a complete and efficient cellulolytic system would be obtained from the cellulose hydrolysis of rice bran.

\section{EXPERIMENTAL SECTION}

\section{Materials}

Rice bran from Sierang type rice was collected from local rice milling in the city of Malang, Indonesia. All media for growth were purchased from Difco, chemicals including metallic, reduction agents from Sigma Aldrich product, materials for biochemical testing of microorganisms use Microbact 12A/E-24E kits from Oxoid Ltd. products, and molecular identification using a primer from Genetica Science.

\section{Instrumentation}

Enzyme activity was measured using UV-Visible spectrophotometer by Varian, amplification of DNA using PCR by Intron, and sequencing analysis was performed using a dye terminator dideoxy method by Sanger Singapore.

\section{Procedure}

\section{Isolation and screening of cellulolytic bacteria}

Twenty-five grams of rice bran that had been lest to decompose for one month was added to an Erlenmeyer flask containing $225 \mathrm{~mL}$ of $0.85 \% \mathrm{NaCl}$ solution and was incubated for two weeks at room temperature. After incubation, a sample of $1 \mathrm{~mL}$ was diluted up to $10^{6}$ times with $0.85 \% \mathrm{NaCl}$ in a Petri dish containing CYPE-agar medium at room temperature for 24-48 h. CYPE-agar consisted of 1\% CMC, $0.5 \%$ peptone, $0.5 \%$ yeast extract, $0.1 \% \mathrm{~K}_{2} \mathrm{HPO}_{4}, 0.02 \%$ $\mathrm{MgSO}_{4}, 0.5 \% \mathrm{NaCl}$, and $2 \%$ agar at $\mathrm{pH} 7$.

The morphology of each colony was observed and then transferred to CYPE-agar slant for purification. The pure isolates obtained were tested for their ability to produce cellulolytic enzymes using Congo red [16]. Colonies of pure isolates flow were treated with $0.1 \%$ Congo red for $15 \mathrm{~min}$ then washed three times using $1 \mathrm{M} \mathrm{NaCl}$. The diameter of the clear zone and colony formed were measured, and cellulase activity was determined from the cellulolytic index. The cellulolytic index is the ratio between the diameter of the clear zone and the diameter of the colony. Isolates with large cellulolytic index ability were selected and used for further treatment.

\section{Growth curve of bacteria}

For each selected isolates one colony was transferred into $50 \mathrm{~mL}$ of CYPE-broth medium and incubated at $120 \mathrm{rpm}$ for $24 \mathrm{~h}$. Thirty milliliters of each inoculum was transferred to $300 \mathrm{~mL}$ similar medium. Samples of $5 \mathrm{~mL}$ were removed every $4 \mathrm{~h}$ until the stationary phase, and absorbance was measured at $600 \mathrm{~nm}$.

\section{Cellulase production by bacteria indigenous of rice bran}

Selected cellulolytic bacteria isolates were incubated on CYPE-broth at room temperature with shaking at $120 \mathrm{rpm}$. The time of cellulase enzyme production was adjusted to a logarithmic growth phase of the growth curve result. The acquired culture was then centrifuged at $10000 \mathrm{rpm}$ for $10 \mathrm{~min}$ at $4{ }^{\circ} \mathrm{C}$ temperature. The resulting supernatant was then used to test the cellulolytic ability and then identify the species of bacteria. 


\section{Cellulase activity assay}

Endo- $\beta$-1,4-glucanase. Endo- $\beta$-1,4-glucanase activity was determined by incubation a mixture of $1 \% \mathrm{CMC}$ in $1800 \mu \mathrm{L} 20 \mathrm{mM}$ phosphate buffer $(\mathrm{pH} 7.0)$ with $200 \mu \mathrm{L}$ of crude extract of cellulase enzymes at $50{ }^{\circ} \mathrm{C}$. After $30 \mathrm{~min}$ of reaction, $2 \mathrm{~mL}$ of 3,5-dinitrosalicylic acid (DNS) was added and boiled in water bath for 5 min to stop the reaction [17]. The sample was then cooled to room temperature and its absorbance was measured at 530 $\mathrm{nm}$ wavelength. One unit of endo- $\beta-1,4$-glucanase activity was defined as the amount of enzyme that could hydrolyze $\mathrm{CMC}$ and released $1 \mu \mathrm{g}$ of glucose equivalent per minute reaction at a $50{ }^{\circ} \mathrm{C}[17]$.

Exo- $\beta-1,4-$ glucanase. Exo- $\beta-1,4$-glucanase activity was determined by incubation of $1 \%$ avicel in $1800 \mu \mathrm{L} 20 \mathrm{mM}$ phosphate buffer ( $\mathrm{pH} 7.0)$ with $200 \mu \mathrm{L}$ of the enzyme at $50{ }^{\circ} \mathrm{C}$ temperature. After $30 \mathrm{~min}$ of reaction, $2 \mathrm{~mL}$ of 3,5dinitrosalicylic acid (DNS) was added and boiled in water bath for $5 \mathrm{~min}$ to stop the reaction. The sample was then cooled to room temperature and its absorbance was measured at $530 \mathrm{~nm}$ wavelength. One unit of exo- $\beta-1,4-$ glucanase activity was defined as the amount of enzyme that could hydrolyze avicel and released $1 \mu \mathrm{g}$ of glucose per minute.

$\beta$-glucosidase. Beta-glucosidase activity was determined by hydrolyzing $1 \%$ cellobiose substrate in $1800 \mu \mathrm{L} 20 \mathrm{mM}$ phosphate buffer $(\mathrm{pH} 7.0)$ with $100 \mu \mathrm{L}$ of crude extract of enzymes at $50{ }^{\circ} \mathrm{C}$. After $30 \mathrm{~min}$ of reaction, $2 \mathrm{~mL}$ of 3,5-dinitrosalicylic acid (DNS) was added and boiled in water bath for five min to stop the reaction. The sample was then cooled to room temperature and its absorbance was measured at 530 $\mathrm{nm}$ wavelength. One unit of $\beta$-glucosidase activity was defined as the amount of enzyme that could hydrolyze cellobiose and released $1 \mu \mathrm{mol}$ of glucose per minute.

\section{Morphological and biochemical characterization of cellulolytic bacteria}

Colony characterization was carried out, included gram staining and endospore function, and macroscopic observations of shape, form, elevation, margin, color, inside the structure. Biochemistry test using Microbact $12 \mathrm{E}$ method.

\section{Identification of bacteria using $16 S$ rDNA}

The isolation of chromosomal DNA used a commercial kit. Furthermore, the 16S rDNA gene amplification process was carried out using PCR. The total volume in the PCR was $25 \mu \mathrm{L}$, containing PCR reaction mixture (DNA polymerase, dNTPs, reaction buffer, gel loading buffer), DNA template $2 \mu \mathrm{L}$, primer $\mathrm{F}$ (forward) and $\mathrm{R}$ (reverse) each $1 \mu \mathrm{L}(10 \mathrm{pmol} / \mathrm{mL})$, and $16 \mu \mathrm{L}$ of distilled water. Primers used were $28 \mathrm{~F}\left(5^{\circ}\right.$-AGA GTT TGA TCA TGG CTC AG-3'), 651F (5'-AAT TAC TGG GCG TAA AG-3`) and 1495R (3`-TAC GGC TAC
CTT GTT ACG A-5) with PCR parameter: $94{ }^{\circ} \mathrm{C}$ preseparation temperature for $4 \mathrm{~min}, 94{ }^{\circ} \mathrm{C}$ separation temperature for $45 \mathrm{sec}, 52{ }^{\circ} \mathrm{C}$ annealing temperature for $45 \mathrm{~min}$ and of $72{ }^{\circ} \mathrm{C}$ polymerization temperature for two minutes over 35 cycles. The results obtained were then visualized by $1 \%$ agarose gel electrophoresis. PCR products were sequenced before then being purified using the PCR Clean-Up System. Determination of the 16S rDNA gene sequences was calculated using Sanger dideoxy dye terminator in Singapore. Results of sequences done contig with Bioedit software. Sequences were analyzed with the results contig BlastN program (Basic Local Alignment and Search Tool for Nucleotides) (www.ncbi.nlm.nih.gov) to determine the similarity with other sequences in GenBank and the phylogenetic tree created with MEGA 6 .

\section{Data analysis}

Data obtained from the study were repeated three times and analyzed using an analysis of variance (ANOVA) test with $0.5 \%$ confidence interval to examine the effect of treatment. If there was an influence, the analysis was then followed by a Tukey test with $0.5 \%$ confidence interval to discover which treatment would be influential or significantly different from other treatments.

\section{RESULT AND DISCUSSION}

\section{Isolation and Screening for Cellulolytic Bacteria}

This study obtained 22 bacterial isolates that were indigenous in rice bran with the ability to produce the cellulolytic enzymes when they were growing on CYPE agar plates. The capability of producing cellulase was demonstrated by the cellulolytic index obtained from the ratio/comparison between the diameter of the clear zone and the diameter of cell colonies using the Congo red method at cell concentrations (Optical Density = 0.4 ) or cell number $0.62 \times 10^{7} \mathrm{cfu}$.

There were six bacterial isolates with the highest cellulase ability (cellulolytic index of over 0.5 ): BE $5, \mathrm{BE}$ 8, BE 14, B 3, B 5 and BT 2 (Fig. 1). Qualitatively, Isolate $\mathrm{BE} 5$ had the highest cellulolytic index of all the isolates, and produced an $11.4 \mathrm{~mm}$ clear zone and a cellulolytic index is 1.78 .

The results are similar to research which reported that cellulolytic from rice bran featured $12 \mathrm{~mm}$ clear zones [18]. Cellulolytic bacterial Isolates from soil produced $43 \mathrm{~mm}$ clear zone [19]. Clear zone resulting from this research were smaller in size, possibly caused by the different sources of rice bran and the amount of inoculum. 


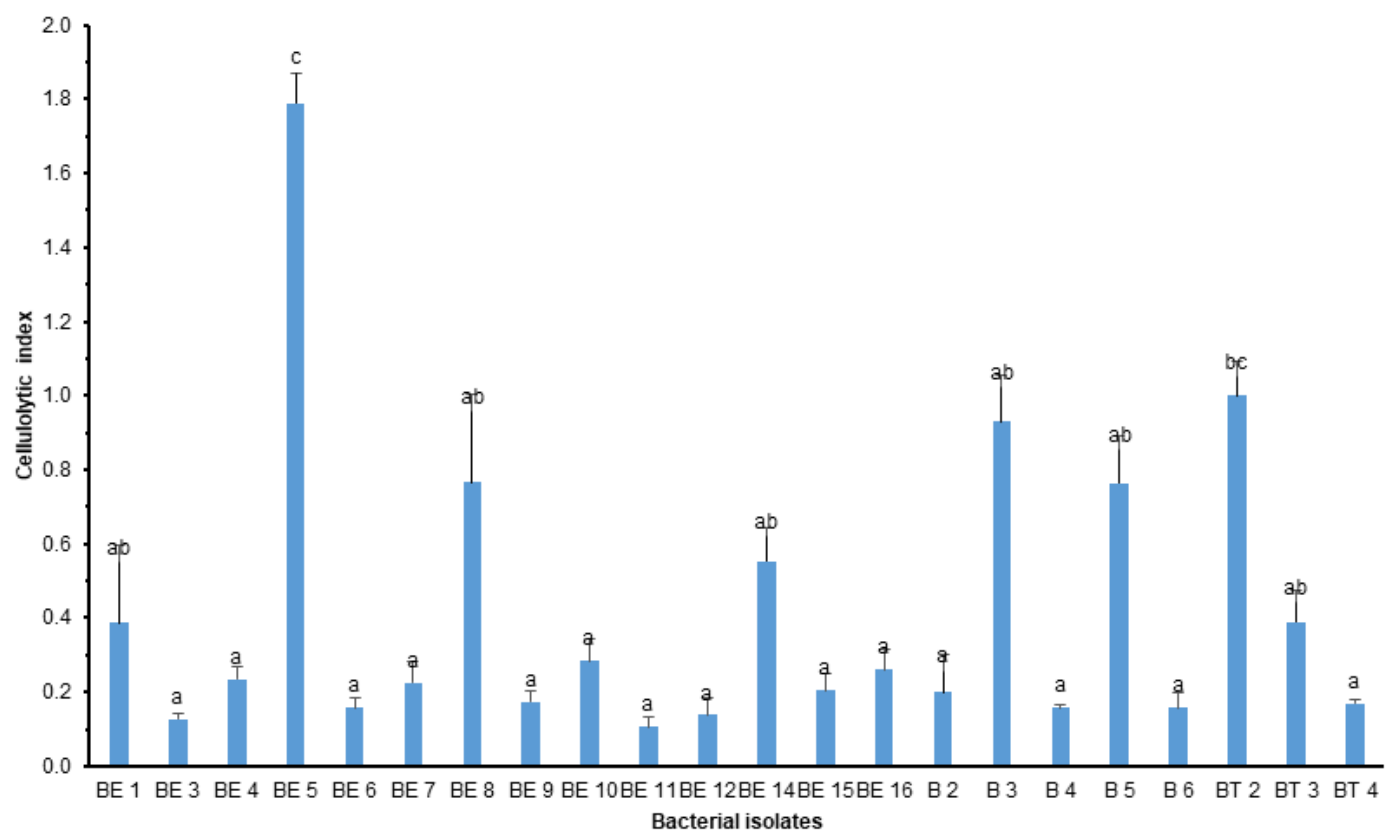

Fig 1. Cellulolytic index of bacterial isolates from rice bran

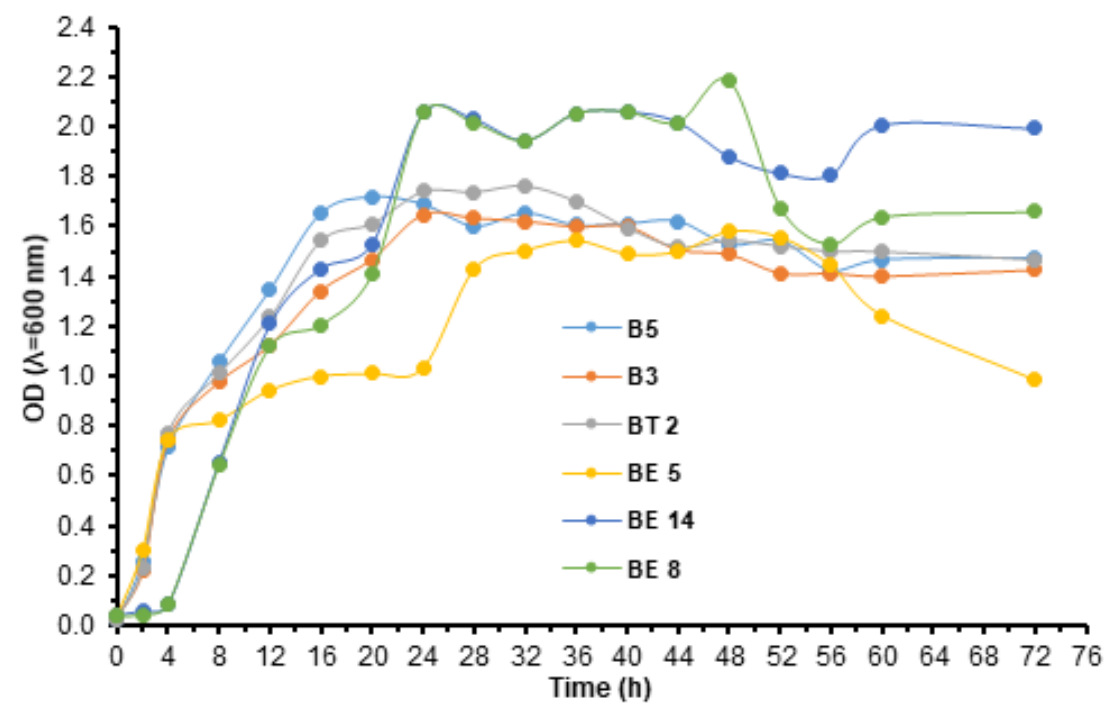

Fig 2. Growth curve of selected bacterial isolate

\section{Growth Curve of Selected Bacterial Isolates}

Analysis of the growth curve of each isolate was performed before testing cellulolytic activity, to determine the fast growth/ exponential phase. The most optimal production of endoglucanase occurred in the last phase of exponential growth. The observations were carried out from 0 to 72 h. Growth curves were plotted as absorbance vs time.

Endoglucanase production can be seen in the growth curve of cellulolytic bacteria. The increased of enzyme production was associated with the increased of cell growth, which indicated that cellulose was actively used by cellulolytic bacteria during the growth phase [20].

Based on Fig. 2, the following features can be seen: the adaptation phase occurred between 0 and 4 $h$ and the exponential phase between 4 and $24 \mathrm{~h}$. The stationary phase was from $24-48 \mathrm{~h}$ for isolate BE 8 , 24-44 $\mathrm{h}$ for isolate BE $14,24-72 \mathrm{~h}$ for BT 2, and 24-56 $\mathrm{h}$ for isolate BE 5, B 3 and B5. From these results it can be concluded that the best production of cellulase enzyme for all isolates is at $24 \mathrm{~h}$.

The result of this study are similar to those of other researchers, in that the exponential phase of BY-2 Bacillus subtilis took $0-20 \mathrm{~h}$, the stationary phase took 
Table 1. Cellulase enzyme activity of indigenous isolate of rice bran

\begin{tabular}{lccc}
\hline \multirow{2}{*}{ Isolates } & \multicolumn{3}{c}{ Activity $(\mathrm{U} / \mathrm{mL})$} \\
\cline { 2 - 4 } & $\begin{array}{c}\text { endo- } \beta-1,4- \\
\text { glucanase }\end{array}$ & $\begin{array}{c}\text { exo- } \beta-1,4- \\
\text { glucanase }\end{array}$ & $\beta$-glucosidase \\
\hline BE 5 & $0.71^{\mathrm{a}}$ & $0.61^{\mathrm{a}}$ & $164.15^{\mathrm{c}}$ \\
BE 8 & $2.16^{\mathrm{c}}$ & $0.64^{\mathrm{a}}$ & $163.66^{\mathrm{c}}$ \\
BE 14 & $1.31^{\mathrm{b}}$ & $0.62^{\mathrm{a}}$ & $164.64^{\mathrm{c}}$ \\
B 3 & $0.73^{\mathrm{a}}$ & $0.61^{\mathrm{a}}$ & $134.28^{\mathrm{a}}$ \\
B 5 & $0.73^{\mathrm{a}}$ & $0.64^{\mathrm{a}}$ & $129.41^{\mathrm{a}}$ \\
BT 2 & $0.72^{\mathrm{a}}$ & $0.61^{\mathrm{a}}$ & $139.74^{\mathrm{b}}$ \\
\hline
\end{tabular}

Table 2. Morphological characterization of the colony from indigenous cellulolytic bacteria of rice bran

\begin{tabular}{lcc}
\hline \multirow{2}{*}{ Test } & \multicolumn{2}{c}{ Isolate } \\
\cline { 2 - 3 } & BE 8 & BE 14 \\
\hline Gram & + & + \\
Shape & Bacill & Bacill \\
Endospore & + & + \\
Form & circular & Irregular \\
Elevation & raised & Undulate \\
Margin & entire & Entire \\
Color & beige & Yellow \\
Inside structure & opaque & transparent \\
\hline
\end{tabular}

20-39 $\mathrm{h}$, and fermentation for the production of cellulase enzymes took $24 \mathrm{~h}$ [21]. The production of cellulase enzymes was conducted for $24 \mathrm{~h}$ [22]. The exponential phase of Bacillus licheniformis JK7 took place over 6-16 $\mathrm{h}$ [20]. Cell growth decline in the stationary phase, caused by the metabolites repression after hydrolysis into glucose and cellobiose. Cellulase enzymes used for further analysis were produced for $24 \mathrm{~h}$ with $0.12 \times 10^{7}$ $(O D=0.4)$ cells and activity was tested based on the ability to hydrolyze a CMC substrate (endo- $\beta$-1,4glucanase), avicel substrate (exo- $\beta$-1,4-glucanase) and cellobiose substrate ( $\beta$-glucosidase).

\section{Enzyme Activity Assay}

The sixth isolates were later quantitatively tested for their ability to produce cellulase enzymes including, endo- $\beta-1,4$-glucanase, exo- $\beta-1,4-$ glucanase, and $\beta$ glucosidase abilities.

The ability of an isolate to hydrolyze a CMC substrate or called endo- $\beta$-1,4-glucanase. The highest endoglucanase activity of $B E 8$ isolate was $2.16 \mathrm{U} / \mathrm{mL}$. In term of the ability to hydrolyze avicel or exo- $\beta-1,4-$ glucanase activity, on average all isolates had the same ability (no significant difference) but with lower activity i.e., $0.6 \mathrm{U} / \mathrm{mL}$ on average. $\beta$-glucosidase activity i.e. the ability to hydrolyze cellobiose, had the highest value among endo- $\beta-1,4$-glucanase and exo- $\beta-1,4$-glucanase activities. This is because the cellulase enzyme was easier to hydrolyze in the substrate with low molecular weight or shorter polymer.
The cellobiose substrate has a molecular structure that consists of 2 glucose monomers. Avicel is more crystalline than $\mathrm{CMC}$, meaning that is was more difficult for cellulose enzyme to hydrolyze avicel $\mathrm{CMC}$. This could be identified from the avicelase activity was lower than for CMCase. Among the factors that affect the rate of enzymatic hydrolysis, cellulose crystallinity was considered the most important.

Gundllapalli et al. [23] state that in the decrease of crystallinity, cellulose becomes more easily enzymatically hydrolyzed. The crystalline structure in cellulose substrate is due to the presence of inter and intramolecular hydrogen bonds. Based on the cellulase activity analysis, two isolates with the highest activity that was BE 8 and $\mathrm{BE} 14$ isolate, and these were therefore then observed for bacterial colony morphology, biochemical test, and molecular identification.

\section{Morphological and Biochemical Characterization of Cellulolytic Bacteria}

The two isolates potentially identified as cellulolytic bacteria BE 8 and BE 14, were the cells characterized morphologically and biochemically using Microbact method 12E.

The resulting from Table 2, observations of colony morphological colony for both isolates indicated many similarities, in that they were gram positive, rodshaped, and endosporic. The difference of both between the isolates lay in form, elevation, margin, color and inside the structure.

Based on the biochemical test (Table 3), it can be seen that isolate BE 8 was able to hydrolyze xylose, mannitol, and arabinose, while isolate BE 14 was able to hydrolyze glucose and maltose. The maximum growth temperature of isolate $\mathrm{BE} 8$ at $45^{\circ} \mathrm{C}$, meanwhile isolate $\mathrm{BE} 14$ could grow in temperature to $50{ }^{\circ} \mathrm{C}$. Isolate $\mathrm{BE} 14$ could not grow on $7 \% \mathrm{NaCl}$ and both isolates were unable to reduce methylene blue. Based on the morphological criteria and the biochemical test indicated on Bergey's manual it was demonstrated that isolates BE 8 and BE 14 were the same genus of Bacillus.

\section{Molecular Identification of Cellulolytic Bacteria}

Of 22 cellulolytic bacterial isolates obtained from rice bran, those selected with highest cellulase activity were BE 8 and BE 14. Molecular identification of cellulolytic bacterial isolates used 16S rDNA gene sequences because in this gene it was more stable and ubiquity toward bacteria that it was appropriate to analyze it at the molecular level [24]. The following are 
Table 3. Biochemical characterization of indigenous cellulolytic bacteria of rice bran

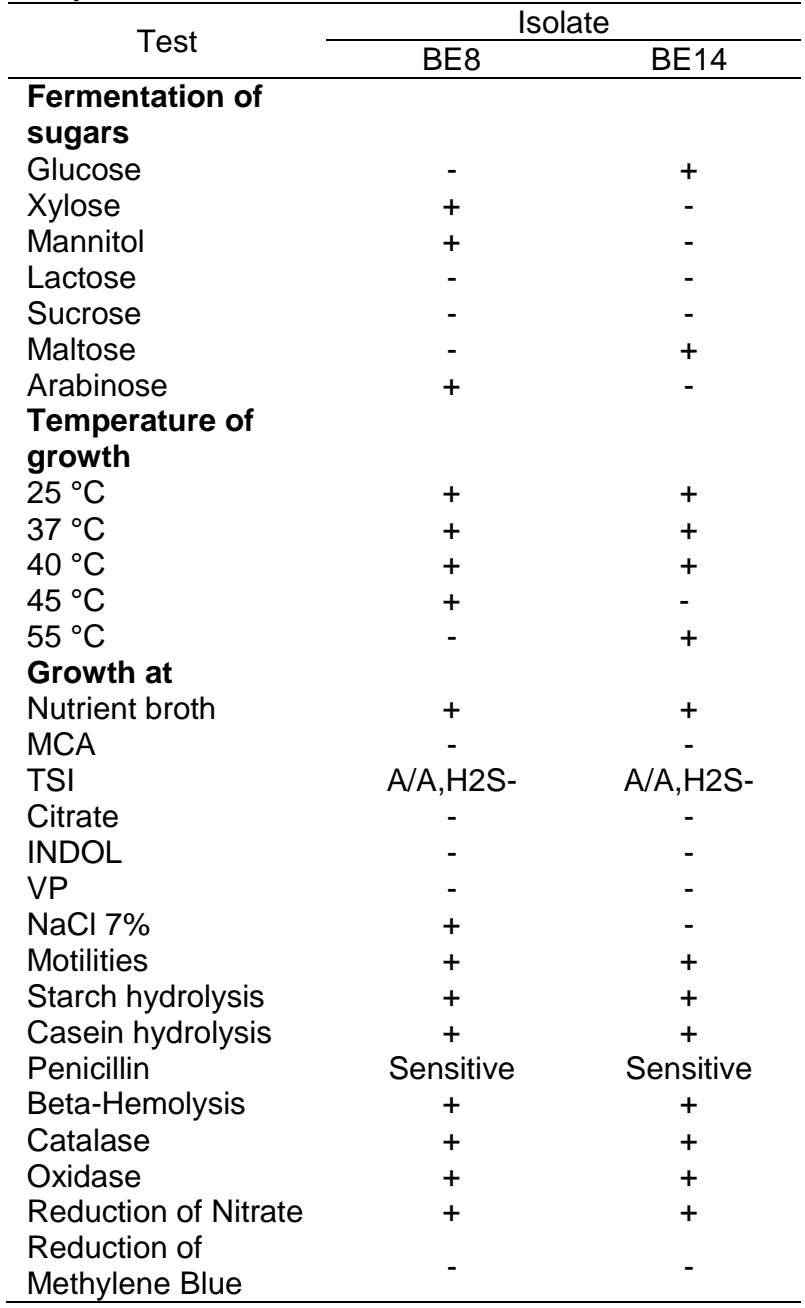

the result of phylogenetic analysis using Maximum Likelihood method (Fig. 3).

BE 8 Isolate was Bacillus subtilis with 99.9\% similarity to the Bacillus subtilis 168 strain (Accession $\mathrm{Nr}$ 102783), Bacillus subtilis J5 (Accession CP018295.1) with $100 \%$ similarity and Bacillus subtilis ZJ2 (Accession KY121111.1) with $100 \%$ similarity. BE 14 isolate was $94.9 \%$ similarity of Bacillus cereus Se05 strain (Accession JN700108.1), Bacillus cereus strain 14759 (Accession NR 0745401), Bacillus cereus strain IIF4SW B1 (Accession KY218861.1), Bacillus cereus strain LC19 (Accession KY534425.1), Bacillus cereus strain MER 27 (Accession KT719607.1), strain Bacillus cereus XH05 (Accession KU986647) and strain Bacillus cereus Y3 (accession GQ462534).

This result was also similar to some studies of rice bran isolate i.e., genus Bacillus $[18,25]$. Most Bacillus groups had the ability to produce cellulase enzyme, such as Bacillus subtilis [26-27], Bacillus licheniformis [6],

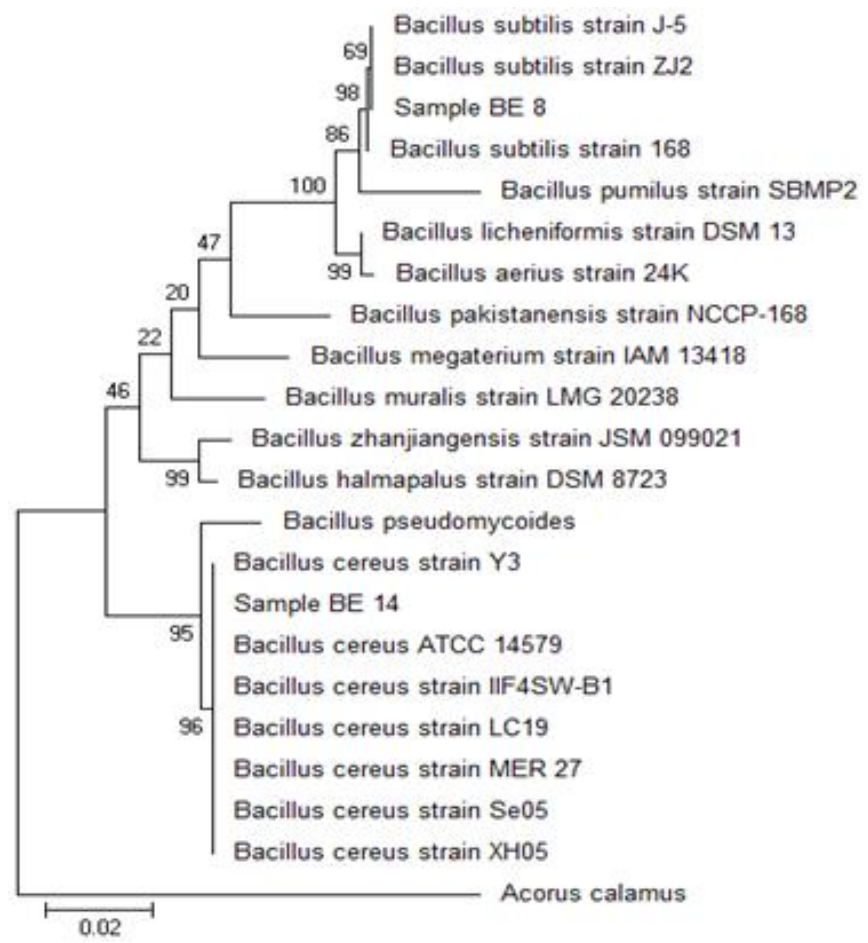

Fig 3. Molecular Phylogenetic analysis using Maximum Likelihood method

Bacillus circulans [18], Bacillus cereus [28], Bacillus pumilus [18], Bacillus brevis [29], Bacillus firmus [30], etc. Bacillus group is used extensively for industrial applications because of its ease of production and because it produces more stable extracellular enzyme [31].

There were two isolates potentially as cellulolytic bacteria -BE 8 and BE 14. The highest CMCase activity was performed by the BE 8 isolate .at $2.16 \mathrm{U} / \mathrm{mL}$ and $\mathrm{BE} 14$ at. $1.31 \mathrm{U} / \mathrm{mL}$. Avicelase activity was low for all isolates, while $\beta$-glucosidase activity was the highest. Based on molecular identification method, it appears that the BE 8 isolate was Bacillus subtilis and BE 14 isolate was Bacillus cereus.

\section{CONCLUSION}

There are two isolates potentially as cellulolytic bacteria -BE 8 and BE 14. The highest CMCase activity is performed by $\mathrm{BE} 8$ isolate, at $2.16 \mathrm{U} / \mathrm{mL}$. Based on molecular identification method, it has been shown that BE 8 isolate is Bacillus subtilis and BE 14 isolate is Bacillus cereus.

\section{ACKNOWLEDGEMENT}

Thanks to the laboratory of Microbiology and Biomol, Brawijaya University, Laboratory of Biochemistry and Genetics at Islamic State University 
of Maulana Malik Ibrahim Malang for supporting this study.

\section{REFERENCES}

[1] Balat, M., and Balat, H., 2009, Recent trends in global production and utilization of bio-ethanol fuel, Appl. Energy, 86, 2273-2282.

[2] Nejadkoorki, F., Nicholson, K., Lake, I., and Davis, T., 2008, An approach for modelling $\mathrm{CO}_{2}$ emissions from road traffic in urban areas, Sci. Total Environ., 406 (1-2), 269-278.

[3] Saini, J.K., Saini, R., and Tewari, L., 2015, Lignocellulosic agriculture wastes as biomass feedstocks for second-generation bioethanol production: Concepts and recent developments, 3Biotech, 5 (4), 337-353.

[4] Toharisman, A., 2007, Etanol dari Tebu, P3GI, http://p3gi.net, accessed on 4 May 2017.

[5] Badan Ketahanan Pangan, 2016, Produksi Beras 2017 Ditarget 77 Juta Ton, http://www.republika.co.id/berita/ekonomi/makro/16/ 08/17/oc2agl368, accessed on 2 April 2017.

[6] Moongngarm, I., Daomukda, N., and Khumpika, S., 2012, Chemical compositions, phytochemicals, and antioxidant, APCBEE Procedia, 2, 73-79.

[7] Faria, S.A.S.C., Bassinello, P.Z., and Penteado, M.V.C., 2012, Nutritional composition of rice bran submitted to different stabilization procedures, Braz. J. Pharm. Sci., 48 (4), 651-657.

[8] Tiwari, S., Jadhav, S.K., and Tiwari, K.L., 2015, Bioethanol production from rice bran with optimization of parameters by Bacillus cereus strain McR-3, Int. J. Environ. Sci. Technol., 12 (12), 38193826.

[9] Nakazawa, H., Okada, K., Kobayashi, R., Kubota, T., Onodera, T., Ochiai, N., Omata, N., Ogasawara, W., Okada, H., and Morikawa, Y., 2008, Characterization of the catalytic domains of Trichoderma reesei endoglucanase I, II, and III expressed in Escherichia coli, Appl. Microbiol. Biotechnol., 81 (4), 681-689.

[10] Maki, M., Leung, K.T., and Qin, W., 2009, The prospects of cellulase-production bacteria for the bioconversion of lignocellulosic biomass, Int. J. Biol. Sci., 5 (5), 500-516.

[11] Li, X., and Gao, P., 1997, CMC-liquefying enzyme a low molecular mass initial cellulose decomposing cellulose responsible for fragmentation from Streptomyces sp. LX, J. Appl. Microbiol., 83 (1), 5966.

[12] Ariffin, H., Abdullah, N., Kalsom, M.S.U., Shiari, Y., and Hassan, M.A., 2006, Production and characterization of cellulase by Bacillus pumilus EB3, Int. J. Eng. Technol., 3 (1), 47-53.
[13] Ahmed, A., and Vermette, P., 2008, Culture-based strategies to enhance cellulase enzyme production from Trichoderma reesei RUT-C30 in bioreactor culture conditions, Biochem. Eng. J., 40 (3), 399407.

[14] Juhasz, T., Kozma, K., Szengyel, Z., and Réczey, K., 2003, Production of $\beta$-glucosidase in mixed culture of Aspergillus niger BKMF 1305 and Trichoderma reesei RUT C30, Food Technol. Biotechnol., 41 (1), 49-53.

[15] Kim, C.H., and Kim, D.S., 1993, Extracellular cellulolytic enzymes of Bacillus circulans are present as two multipleprotein complex, Appl. Biochem. Biotechnol., 42 (1), 83-94.

[16] Lin, L., Meng, X., Liu, P., Hong, Y., Wu, G., Huang, X., Li, C., Dong, J., Xiao, L., and Liu, Z., 2009 , Improved catalytic efficiency of endo-beta1,4-glucanase from Bacillus subtilis BME-15 by directed evolution, Appl. Microbiol Bitechnol., 82 (4), 671-479.

[17] Zhang, Y.H.P., Himmel, M.E., and Mielenz, J.R., 2006, Outlook for cellulase improvement: Screening and selection strategies, Biotechnol. Adv., 24 (5), 452-481.

[18] Nirmala, P., and Sindhu, A., 2011, Production of endoglucanase by optimizing the environmental conditions of Bacillus circulans on submerged fermentation, IJAER, 2 (2), 472-481.

[19] Liang, Y.L., Zhang, Z., Wu, M., Wu, Y., and Feng, J.X., 2014, Isolation, screening, and identification of cellulolytic bacteria from natural reserves in the subtropical region of China and optimization of cellulase production by Paenibacillus terrae ME271, BioMed Res. Int., 2014, 512497.

[20] Seo, J.K., Park, T.S., Kwon, I.H., Piao, M.Y., Lee, C.H., and Ha, J.K., 2013, Characterization of cellulolytic and xylanolytic enzymes of Bacillus licheniformis JK7 isolated from the rumen of a native Korean goat, AJAS, 26 (1), 50-58.

[21] Yang, W., Meng, F., Peng, J., Han, P., Fang, F., $\mathrm{Ma}$, L., and Cao, B., 2014, Isolation and identification of a cellulolytic bacterium from the Tibetan pig's intestine and investigation of its cellulose production, Electron. J. Biotechnol., 17 (6), 262-267.

[22] Meng, F., Ma, L., Yang, W., and Cao, B., 2014, Isolation and characterization of Bacillus subtilis strain BY-3, a thermophilic and efficient cellulaseproducing bacterium on untreated plant biomass, Lett. Appl. Microbiol., 59 (3), 306-312.

[23] Gundllapalli, S.B., Pretorius, I.S., and Cordero Otero, R.R., 2007, Effect of the cellulose-binding domain on the catalytic activity of a betaglucosidase from Saccharomycopsis fibuligera, J. Ind. Microbiol. Biotechnol., 34 (6), 413-421. 
[24] Singh, A.K., Maharana, A.K., Masih, H., Kumar, Y., and Mishra, S.K. 2012, Production, optimization and purification of bacterial cellulase by solid state bioprocessing of agro biomass, RJPBCS, 3 (2), 977-989.

[25] Bajaj, B.K., Pangotra, H., Wani, M.A., Sharma, P., and Sharma, A., 2009, Partial purification and characterization of a highly thermostable and $\mathrm{pH}$ stable endoglucanase from a newly isolated Bacillus strain M-9, Indian J. Chem. Technol., 16. 382-387.

[26] Yin, L.J., Lin, H.H., and Xiao, Z.R., 2010, Purification and characterization of a cellulase from Bacillus subtilis YJ1, J. Mar. Sci. Technol., 18 (3), 466-471.

[27] Kim, Y.K., Lee, S.C., Cho, Y.Y., Oh, H.J., and Ko, Y.H., 2012, Isolation of cellulolytic Bacillus subtilis strains from agricultural environments, ISRN Microbiol., 2012, 650563.
[28] Yan, H., Dai, Y., Zhang, Y., Yang, L., and Liu. D., 2011. Purification and characterization of an endo1,4- $\beta$-glucanase from Bacillus cereus, Afr. J. Biotechnol., 10 (72), 16277-16285.

[29] Fatema, K., and Manchur, M.A., 2015, Isolation, identification and cellulase production by Bacillus brevis from the Acacia forest soil, IJRAF, 2 (9), 14-22.

[30] Zainudin, M.H., Hassan, M.A., Tokura, M., and Shirai, Y., 2013, Indigenous cellulolytic and hemicellulolytic bacteria enhanced rapid cocomposting of lignocellulose oil palm empty fruit bunch with palm oil mill effluent anaerobic sludge, Bioresour. Technol., 147, 632-635.

[31] Rastogi, G., Bhalla, A., Adhikari, A., Bischoff, K.M., Hughes, S.R., Christopher, L.P., and Sani, R.K., 2010, Characterization of thermostable cellulases produced by Bacillus and Geobacillus strains, Bioresour. Technol., 101 (22), 8798-8806. 